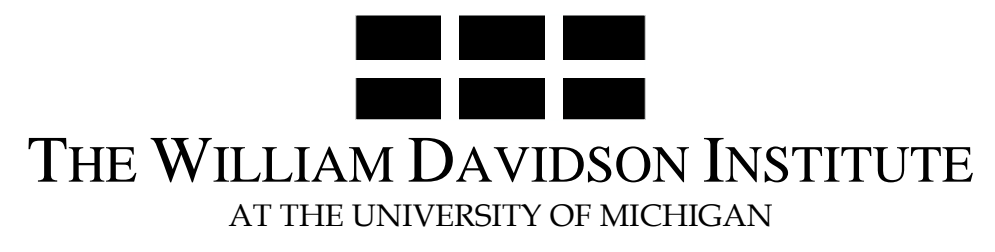

AT THE UNIVERSITY OF MICHIGAN

\title{
Default Rates in the Loan Market for SMEs: Evidence from Slovakia
}

By: Jarko Fidrmuc, Christa Hainz and Anton Malesich

William Davidson Institute Working Paper Number 854

November 2006 


\title{
Default Rates in the Loan Market for SMEs:
}

\section{Evidence from Slovakia*}

\author{
Jarko Fidrmuc ${ }^{\mathrm{I}, \#}$ \\ Christa Hainz ${ }^{\text {II }}$ \\ Anton Malesich $^{\text {III }}$
}

November 2006

\begin{abstract}
Banks entering an emerging market face a lot of uncertainty about the risks involved in lending. We use a unique unbalanced panel of nearly 700 shortterm loans made to SMEs in Slovakia between January 2000 and June 2005. Of the loans granted, on average 6.0 per cent of the firms defaulted. Several probit models and panel probit models show that liquidity and profitability factors are important determinants of SMEs defaults, while debt factors are less robust. However, we find that above average indebtedness significantly increases the probability of default. Moreover, the legal form that determines liability has important incentive effects.
\end{abstract}

Keywords: SME, Credit, Loan Default, Mortality Rates, Incentives, Probit, Panel Data.

JEL Classification:.G33, G21, C25

\footnotetext{
* The authors would like to thank Zuzana Fungacova, Peter Huber, David Kemme, Stefanie Kleimeier, Monika Schnitzer and seminar participants at the University of Munich, the Annual Meeting of Austrian Economic Association in Vienna, and the participants of the Conference on Risk, Regulation and Competition: Banking in Transition Economies in Ghent for helpful comments and suggestions. The usual disclaimer applies. Christa Hainz gratefully acknowledges financial support from the German Science Foundation, under SFB-Transregio 15.

I Department of Economics, University of Munich; CESifo; and Comenius University Bratislava, Faculty of Mathematics, Physics and Informatics, Slovakia. Address: University of Munich, Geschwister-SchollPlatz 1, 80539 Munich, Germany, Tel.: +49-89-21805544, e-mail: jarko.fidrmuc@1rz.uni-muenchen.de.

II Department of Economics, University of Munich, CESifo, and WDI. Adress: University of Munich, Akademiestr. 1/III, 80799 Munich, Tel.: +49-89-21803232, e-mail: christa.hainz@1rz.uni-muenchen.de.

III Comenius University Bratislava, Faculty of Mathematics, Physics and Informatics, Slovakia, e-mail: antonmalesich@orangemail.sk.

\# Corresponding author.
} 


\section{Introduction}

The current trends in the banking markets in the new member states of the European Union (EU) may seem puzzling. On the one hand, they are attractive targets for Western European banks that now posses most of the banks assets in nearly all the countries of this region. Currently, the investments made by foreign banks in these countries pay off, and actually generate higher revenues than their activities in their home markets (Breyer, 2004). Still, many firms in the new member states complain that access to finance represents a major impediment to doing business. SMEs find it particularly difficult to get loans. In Eastern Europe, only about 45 per cent of SMEs use external finance while 65 per cent of the large firms do so (EBRD, 2005a). This means that, due to the lack of financial intermediation, their potential contributions to growth and employment are wasted (Bilsen and Konings, 1998, Levine, 2006). Thus, these markets can be expected to keep growing in the future provided the firms are credit-worthy.

On the other hand, fueled by increasing income and positive growth expectations, lending has increased significantly (Coricelli et al., 2006). From a macroeconomic perspective, however, concerns about a "lending boom" have been

raised recently (Duenwald et al., 2005). ${ }^{1}$ An expansion of credit may increase the probability of a banking crisis if, during the credit boom period, the quality of the evaluation of credit proposals suffers.

However, we know little about the default rates of bank loans. Although there is evidence on the default and mortality rates of bonds, it is hard to transfer the results in this field to corporate loans. The sole study on default of bank loans is on syndicated loans to corporate debtors (Altman and Suggitt, 2000). What is still missing is evidence of the default pattern of loans to individual firms in a fast growing emerging economy. 
What are the typical default rates of loans to SMEs which are not rated? Is there a difference in default rates across sectors? Is there a common pattern in the financial indicators and the business development of defaulters? What is the role of the incentives related to the liability requirements for different legal forms of the SMEs?

We analyze these issues by using a unique set of data about loans made to around 700 SMEs in Slovakia between January 2000 and June 2005. We find that the default rate among loans made to SMEs was 6.0 per cent. It can also be shown that the conditional default probabilities (or marginal mortality rates) are hump shaped, with the highest mortality rate reached about three years after the credit approval. The default rates clearly differ between industries: in the service sector and in agriculture the default rates are above average. Moreover, the default rate is much lower for natural persons than for legal bodies. We also provide evidence that lower profitability and lower liquidity increase the risk of default. Furthermore, we show that indebtedness increases the risk of default only for highly indebted firms.

The paper is organized as follows. The next section provides a survey of the literature on loan defaults and derives the predictions to be tested empirically. Section 3 describes our data set, and Section 4 presents mortality rates for bank loans. Section 5 analyses factors determining the probability of a default in probit models. The last section concludes.

\section{Determinants of Default Rates and Literature Review}

Our paper is related to the literature on default rates and the problems of asymmetric information. Problems of asymmetric information play an important role in financing SMEs. These problems - adverse selection and ex ante moral hazard - should be more severe in the new member states of the EU. According to the so-called "observed-risk 
hypothesis", banks can observe the firm's risk ex ante and can adjust the terms of the credit contract accordingly so as to adjust pricing to the riskiness of the loan (Blazy and Weill, 2006).

Correspondingly, we concentrate on three areas of default determinants. Firstly, the problems of asymmetric information arise for all loans, although these problems aggravate as the relative debt level increases. Secondly, however, different legal forms may also provide different incentives, which may result in different default probabilities. Finally, other variables are also likely to determine the default rates.

The first relationship is most closely related to our initial motivation with regard to financial vulnerability in the new member states. If firms are highly indebted, when successful they have to pay a higher proportion of their payoff to the bank. As a result, ceteris paribus, the difference between the payoffs for success and failure decreases, and so does the incentive to exert effort and/ or invest the loan for the purpose agreed upon in the credit contract. This behavior decreases the probability of success.

Hypothesis 1: More highly indebted firms are more likely to default.

The degree of the moral hazard problems depends a lot on the characteristics of the firm. If the debtor is fully liable, he internalizes the effect of his investment decision on payoffs. In contrast, when the degree of debtor's liability is restricted, for example, if he does not have sufficient assets that can be used as collateral ${ }^{2}$ and can be liquidated in the case of failure, the debtor repays only in the case of a successful outcome. Of course, he has to repay more in the case of success because with failure, the bank gets 
no repayment. As a consequence, the incentives of the debtor are distorted if he is not (fully) liable (see Bester, 1987, Holmström, 1996, and Hainz, 2003).

A similar argument applies to strategic default. Suppose that the creditor cannot observe the actual outcome of a project. This allows the debtor to claim that his project hasfailed (although it was successful) and to keep the return. If the debtor is liable and loses assets in the case of failure, the likelihood of strategic default is much lower (see Bester, 1994). The debtor's liability is largely determined by the legal form. On the one hand, natural persons are fully liable for their losses. On the other hand, owners can limit their liability more easily by incorporating the firm as a legal body.

Hypothesis 2: The higher is the debtor's liability, the less likely the firm is to default.

Finally, we have to consider other determinants of corporate defaults that were discussed in the earlier literature. Loan default is closely related to corporate bankruptcy. The causes of bankruptcy are problems in the fields of profitability, liquidity and solvency (Altman, 1968). These financial ratios can be used to predict the probability of corporate bankruptcy (Altman, 1968; Beaver, 1966). ${ }^{3}$

Hypothesis 3: Firms are more likely to default if they are less profitable and less liquid.

The only paper studying default rates of bank loans is Altman and Suggitt (2000). They base their analysis on syndicated loans which exceed US\$ 100 million, are rated and are issued between 1991 and 1996. After a five year period, the cumulative default rates are remarkable similar to those of corporate bonds. However, the time 
patterns of default differ considerably. Compared to bonds the default rates of loans are significantly higher in the first two years. Some more evidence is available on the default recovery rates of loans that range between mean values of 65 and 87 per cent in developed countries, depending on the data set (Carty et al. 1998; Asarnow and Edwards, 1995; Grossman et al., 1997).

\section{Data Description}

We have a unique data set on small and medium enterprises (SMEs) in Slovakia between 2000 and 2005. Our data set is from a major commercial bank in Slovakia that provided all types of loans in all regions of the country. Lending to the SMEs represents an important growth strategy. Similarly to other banks in the region, the bank was privatized to a large Western European banking group before the period analyzed here. As a result, our analyses are likely to be applicable to other countries of the enlarged EU, although we cannot present direct comparisons.

The anonymous data set is used for an ex post evaluation of the credit risk of various types of the SMEs. Our data set consists of two parts. First, we have information about whether a SME defaulted on its loan during five partially overlapping periods of 18 months, which are starting in January (e.g. the first period being January 2000 to June 2001, the last period being January 2004 to June 2005). Default companies are dropped from the sample after the period in which insolvency occurred. In order to preserve a consistency between the time periods, clients who repaid their loans before the end of period analyzed were not included in the sample. ${ }^{4}$ We include only SMEs with double-entry bookkeeping in order to ensure a more reliable and comparable data base. 
Following the general practice of the financial institutions, we define defaults if a loan is written off, or after the delay in repayment exceeds 90 days, or a client is classified by the bank as substandard, doubtful or loss-making during the observed period. With a few exceptions, the bank terminated the relationships with defaulting companies after either eventual repayment of the obligations or the company became bankrupt. We do not have any data for recoveries of defaulting companies, which are supervised by a specialized unit of the bank. Figure 1 shows that the development of credits and defaults during the period analyzed. We can see only a slightly higher default rate between January 2002 and June 2003, which corresponded to the business cycle in Slovakia. Similarly, we can see a moderate expansion of credits to the SMEs in 2004 and 2005. This development pattern approximately follows the credit development in Slovakia. According to the National Bank of Slovakia (see NBS, 2006), between 1999 and 2005 the volume of credits to SMEs grew by 1.4 per cent on average. More recently, however, this segment expanded by 39 per cent and 19 per cent in 2004 and 2005 , respectively. ${ }^{5}$ 
Figure 1: Development of Loans and Defaults by Reporting Periods

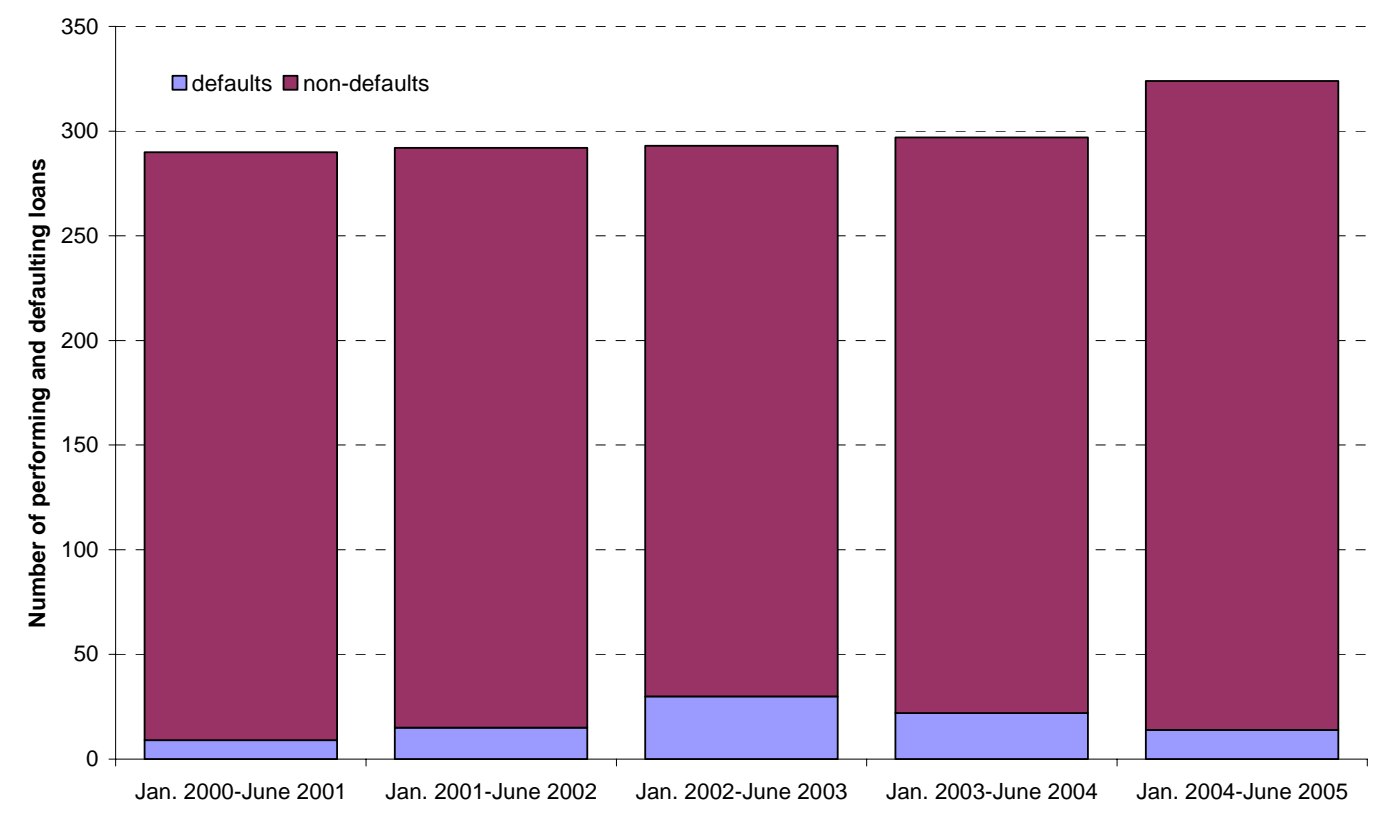

This information set on defaults is merged with financial data from the firms' annual balance sheets published in December of the respective year before the reported period (e.g. December 1999 is used for the explanation of defaults between January 2000 and June 2001). All items are reported as shares in total assets or liabilities. Total sales indicate the size of the SMEs, and they are also used for the definition of the SMEs as being between SKK 30 million (approximately EUR 1 million) and SKK 300 million (approximately EUR 10 million). The same nominal interval was applied during the whole available period, while the average inflation was about 8 per cent annually. However, the majority of the reported entities has total sales in the lower range of the spectrum. The descriptive statistics for the sales in Table 1 show that there is only weak statistical evidence that the size of the defaulting SMEs is larger than that of the whole data sample. ${ }^{6}$ In particular, the $F$-test for the equality of means of sales of defaulting and 
non-defaulting companies can be rejected only at $10 \%$ significance level, while variances in the sub-samples are not significantly different.

Table 1: Descriptive Statistics of Selected Variables

\begin{tabular}{|c|c|c|c|c|}
\hline & $\begin{array}{r}\text { Total sales } \\
\text { SKK million }\end{array}$ & $\begin{array}{l}\text { Bank } \\
\text { loans }^{B}\end{array}$ & $\begin{array}{r}\text { Cash and bank } \\
\text { accounts }^{\mathrm{A}}\end{array}$ & $\begin{array}{r}\text { Earnings before } \\
\text { taxation }^{\mathrm{A}}\end{array}$ \\
\hline \multicolumn{5}{|c|}{ A: Non-default companies } \\
\hline Mean & 100319 & 0.152 & 0.298 & 0.033 \\
\hline Median & 78046 & 0.117 & 0.146 & 0.019 \\
\hline Max & 298431 & 0.853 & 27.727 & 0.488 \\
\hline Min. & 30115 & -0.190 & -0.237 & -0.321 \\
\hline Std. Dev. & 65584 & 0.125 & 0.832 & 0.078 \\
\hline \multicolumn{5}{|c|}{ B: Default companies } \\
\hline Mean & 114200 & 0.177 & 0.100 & -0.038 \\
\hline Median & 89271 & 0.118 & 0.054 & -0.001 \\
\hline Max & 291358 & 0.666 & 0.715 & 0.171 \\
\hline Min. & 30142 & 0.006 & -0.120 & -0.617 \\
\hline Std. Dev. & 71465 & 0.147 & 0.138 & 0.119 \\
\hline \multicolumn{5}{|c|}{$\begin{array}{l}\text { C: F-Test of equal mean and } \\
\text { variance between the sub-samples }\end{array}$} \\
\hline Mean & $3.747^{*}$ & $3.258^{*}$ & $5.082^{* *}$ & $66.804^{* * *}$ \\
\hline p-value & 0.053 & 0.071 & 0.024 & 0.000 \\
\hline Variance & 1.187 & $1.381^{*}$ & $36.439^{* * *}$ & $2.343^{* * *}$ \\
\hline$p$-value & 0.300 & 0.052 & 0.000 & 0.000 \\
\hline
\end{tabular}

Notes: $\mathrm{A}$ - shares of total assets, $\mathrm{B}$ - shares of current short-term liabilities. $*, * *, * * *$ denote significance at the 10,5 and 1 per cent level, respectively. 
For the whole period, we have 1496 observations available for 667 SMEs. Of this number, 90 SMEs (6.0 per cent of observations) defaulted on their loan during the observation period. Among all Slovak banks, the average share of non-performing loans in total assets decreased from 24.3 per cent in 2000 to 7.2 per cent in 2004 (EBRD, 2005a). Thus, the quality of the bank's portfolio is above average. Since we expect loans to SMEs to be among the relatively more risky segments of the credit market, the quality must be significantly above average. However, loans to SMEs so far are only a very small fraction of the bank's total loan portfolio. Even in an international comparison, the default rates we observe in our analysis are surprisingly low. For example, Altman and Suggit (2000) report average default probabilities for a five year period (measured by a similar indicator based on the number of issuers) of 4.6 per cent for loans to companies with an original S\&P rating B and 23.5 per cent for companies with rating $\mathrm{Caa}^{7}$

In each year, we have about 300 observations. However, there are only few SMEs with a longer history at the bank. Moreover, we do not have any information about them before and after the credit window. This is also true if the SMEs had had earlier credits provided by the bank analyzed. As a result, the average reported duration of the lending relationship between the SME and the bank in the last available period (January 2004-June 2005) is 2.6 years. This is largely comparable to an average loan length of 29 months as reported by EBRD (2005b). In total, 68 of 324 reported SMEs had continued to do business with the bank during the whole period. There are also few SMEs with credit relationships in only a few selected years of the whole period.

Limited liability companies (denoted by S.R.O.) represent over half of the sample. Their default probabilities of approximately 5.4 per cent are slightly below the 
average. The joint stock companies (denoted by A.S.) and cooperatives represent 24 per cent and 20 per cent of the sample with default probabilities of approximately 7 per cent in both categories. Our data sample also involves 66 loans to private businesses of natural persons with only one single default (1.5 per cent). Finally, we have three loan cases of small state enterprises with no defaults.

\section{Mortality Rates}

The seminal paper on measuring default risk is Altman (1989). Instead of deriving default rates he assesses the expected mortality of bonds in a way that actuaries measure the mortality of human beings. He relates his results to the pricing of bonds and finds that, after taking into account the mortality risk, return spreads are positive. The higher the risk of a bond, the higher this spread is. Altman (1989) proposes a mortality rate approach to measuring the risk of bonds according to their maturity, and Altman and Suggit (2000) apply this concept also to bank loans. They define marginal mortality rate $(M M R)$ as

$$
M M R^{t}=\frac{\sum_{j=1}^{F} D_{j}^{t}}{\sum_{i=1}^{N} C_{i}^{t}},
$$

where the nominator, $D$, represents the total value of default loans and the denominator, $C$, represents the sum of all loans (including those of default companies) in period $t=1$, $\ldots, T$ years after start of the loan. This concept considers various ways of terminating a loan in the previous years (in our case either full repayment or defaults). Thus, the marginal mortality rate is a more appropriate indicator for the risk assessment than simple average default rates. 
Figure 2 presents the resulting marginal mortality rates for the Slovak SMEs. Marginal mortality rates show that the loans are relatively safer in the first year after issue. Only 4.0 per cent of loans are not repaid in the first year after the approval, and the risk increases slightly to 5.5 per cent in the second year after the loan was granted. However, the risk of lending increases if the loan is not repaid within two years after the issue. The marginal mortality rate reaches its peak in the third year after the issue with nearly 10 per cent. This is revealed by comparably high cumulative mortality rates, CMR, which are defined as

$$
C M R^{T}=1-\prod_{t=1}^{T}\left(1-M M R^{t}\right)
$$

The cumulative mortality rate for the loans after two years of survival is 20 per cent (cumulative mortality rate over the whole period of five years is thus 27 per cent). However, we have to interpret these results carefully. On the one hand, at least some open loan operations will not be repaid after five years either, and this will further increase the cumulative mortality rate. On the other hand, our results for loans with longer maturity are based only on few observations.

We can compare the behavior of marginal mortality rates with the pattern which Altman and Suggit (2000) report for large syndicated bank loans. They find relatively high default probabilities in the first two years after the issue. In contrast to their analysis, the loans in our sample are short-term loans. Therefore, we would expect that the default rates in our sample to be lower. Indeed, the default rates in our sample are slightly lower than of those Altman und Suggit (2000) report for firms with the speculative ratings (Caa). These results may indicate that some bad loans are refinanced for some time. Therefore, we do not restrict our analysis to matured loans only because 
this could bias the results downwards (see Asch, 1995). Unfortunately, we do not have any information on refinancing schedules of loans analyzed.

\section{Figure 2: Marginal Mortality Rates}

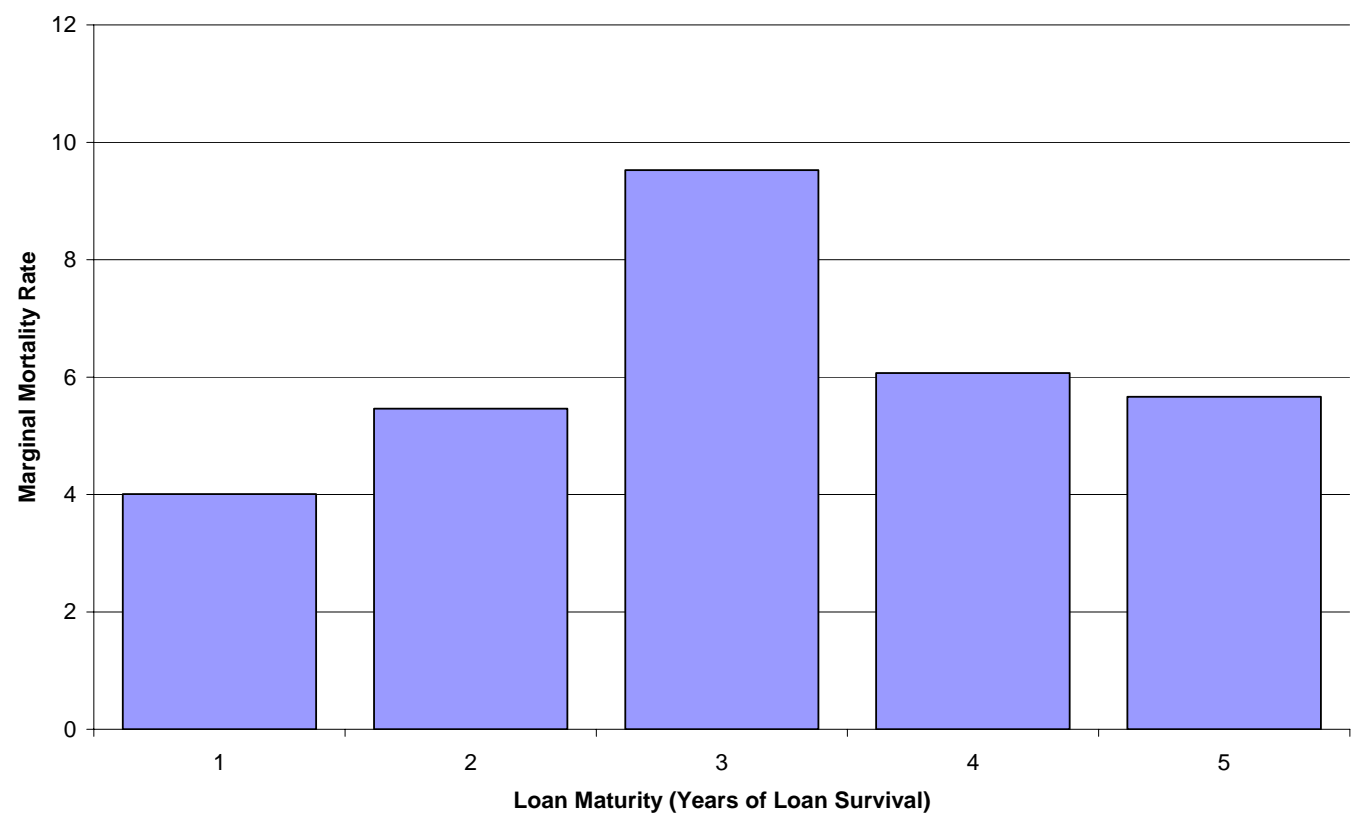

\section{Factors Influencing the Probability of Default}

\subsection{Estimation}

In centrally planned economies, entrepreneurship was not supported either with respect to allowing the private property, or in the management of state enterprises. Furthermore, the central planning system that was applied in Slovakia, which was a part of Czechoslovakia before 1993, was even more regulated than in several other countries of the region (Poland or Hungary). Therefore, management skills in this area were very restricted at the beginning of economic transition in 1990s. There was only a small group of employees with experience in the management of rather large state enterprises 
when economic life was fully controlled by the government. Most people did not have any experience of private business. Furthermore, their capital stock for starting new operations was not sufficient either. For SMEs, EBRD (2005a) show that low access to credit is one the most important business constraints on small private firms. This is not surprising as SMEs have a fundamentally different history than that of state-owned firms and therefore do not possess the networks and the political support that allows easy access to loans. Lízal and Švejnar (2001) find evidence of a soft budget constraint, mainly for the former state enterprises in the Czech Republic and Slovakia in the early reform years.

We estimate several specifications of probit models for loan defaults of SMEs in Slovakia between January 2000 and June 2005 (that is, for five partially overlapping periods). Our dependent variable is the conditional probability at time $t$, given the available information set on the firm $i$ time $t-1, \Omega$, that the firm defaults on its loan,

$$
P\left(q_{t}^{i}=1 \mid \Omega_{t-1}\right)=\beta_{1}+\beta_{2} C_{t-1}^{i}+\mathbf{Z}_{t-1}^{i} \gamma+\varepsilon_{t}^{i},
$$

where $C$ denotes bank loans as a share of total assets and $\mathbf{Z}$ is a vector of control variables describing the performance of the SMEs with the corresponding coefficient vector $\gamma$. We do not include any explanatory variables that characterize the bank structure, because all loans are reported by a single bank. However, we include time effects in selected specifications which may also reflect the business cycle and bankspecific developments.

Our data sample does not include companies without bank loans. ${ }^{8}$ Nevertheless, the descriptive statistics in Table 1 show that the share of credits is relatively small on average (15 per cent of total liabilities). In turn, we have SMEs from those with nearly zero loans up to those with 85 per cent of total liabilities. Thus, this indicates that the 
selection bias should not play an overwhelmingly important role in our data set. Furthermore, the dummies for years, industries and legal forms are likely to reduce selection bias as well (see Djankov and Murrell, 2002).

Equation (3) includes factors mentioned in the rich literature on enterprise restructuring in transition economies (see Djankov and Murrell, 2002), default probability estimations (see Chan-Lau, 2006), and credit scoring models (see Mester, 1997). Bris et al. (2006) estimate a similar logit model of default recoveries in the US. Furthermore, the control variables follow the traditional literature on financial ratios and bankruptcies reviewed by Altman (1968) and Beaver (1966). However, our model concentrates on fewer variables than credit scoring models (see Mester, 1997, Berger et al., 2005) because we include only robust variables that can be also easily interpreted. ${ }^{9}$

Table 1 shows that the mean and variance of the selected financial ratios between the sub-samples are significantly different between the sub-samples of default and non-default SMEs. By contrast, there is only weak evidence that the mean or variance of bank loans are different between the two sub-samples.

\subsection{Effect of Financial Ratios}

According to hypothesis 1 , firms are more likely to default the less liquid and the less profitable they are. Based on the existing literature on bankruptcy, we selected two control variables which are crucially important for the financial wealth of the firms. First, the SMEs that have of relatively higher cash amounts and finance available in their bank accounts (relative to total assets) are significantly less likely to default on their loans in the next 18 months than the rest of the sample. This variable reflects the liquidity and solvency channels. Second, companies that have high earnings before 
taxation (as a share of total assets) are also less likely to default on their loan in the following reporting period than the average of the sample. This channel indicates the profitability of the SMEs stressed in the earlier literature.

From the point of view of the discussion on financial ratios, bank loans as a share of current short-term liabilities represent the debt factors of financial distress. Both the theoretical literature on agency problems and the empirical literature on the determinants of corporate bankruptcy, as formulated in hypotheses 3 and 1 respectively, suggest that more highly indebted firms are more likely to default. 
Table 2: Determinants of Loan Default, January 2000 - June 2005

\begin{tabular}{|c|c|c|c|c|c|c|c|c|c|c|c|}
\hline & $\mathbf{P 1}$ & $\mathbf{P} 2$ & P3 & P4 & P5 & P6 & P7 & P8 & P9 & P10 & P11 \\
\hline \multirow[t]{2}{*}{ Cash and bank accounts ${ }^{\mathrm{A}}$} & $-1.675^{* * *}$ & $-0.116^{* * *}$ & $-1.804^{* * *}$ & $-0.099^{* * *}$ & $-2.551^{* * *}$ & $-0.060^{* * *}$ & $-1.555^{* * *}$ & $-0.117^{* * *}$ & $-2.205^{* * *}$ & $-2.571^{* * *}$ & $-2.392^{* * *}$ \\
\hline & $(0.392)$ & $(0.019)$ & $(0.416)$ & $(0.017)$ & $(0.683)$ & $(0.020)$ & $(0.554)$ & $(0.034)$ & $(0.566)$ & $(0.673)$ & $(1.003)$ \\
\hline \multirow[t]{2}{*}{ Bank loans ${ }^{B}$} & $0.797^{*}$ & $0.055^{*}$ & $1.195^{* *}$ & $0.066^{* *}$ & -0.587 & -0.014 & $1.733^{* * *}$ & $0.131^{* * *}$ & 0.791 & $1.474^{*}$ & $2.948^{* *}$ \\
\hline & $(0.409)$ & $(0.029)$ & $(0.484)$ & $(0.028)$ & $(2.834)$ & $(0.066)$ & $(0.659)$ & $(0.050)$ & $(0.619)$ & $(0.809)$ & $(1.325)$ \\
\hline \multirow[t]{2}{*}{ Earnings before taxation ${ }^{\mathrm{A}}$} & $-4.612^{* * *}$ & $-0.320^{* * *}$ & $-5.214^{* * *}$ & $-0.287^{* * *}$ & $-7.691^{* * *}$ & $-0.180^{* * *}$ & $-3.561^{* * *}$ & $-0.268^{* * *}$ & $-5.294^{* * *}$ & $-6.621^{* * *}$ & $-4.865^{* * *}$ \\
\hline & $(0.728)$ & $(0.063)$ & $(0.815)$ & $(0.062)$ & $(1.421)$ & $(0.081)$ & $(1.127)$ & $(0.093)$ & $(1.042)$ & $(1.351)$ & $(2.063)$ \\
\hline \multirow[t]{2}{*}{ Constant } & $-1.381^{* * *}$ & & $-1.073^{* * *}$ & & $-1.761^{* * *}$ & & $-1.720^{* * *}$ & & $-1.848^{* * *}$ & $-1.475^{* * *}$ & $-2.762^{* * *}$ \\
\hline & $(0.100)$ & & $(0.237)$ & & $(0.533)$ & & $(0.399)$ & & $(0.217)$ & $(0.431)$ & $(0.906)$ \\
\hline Estimation method & Probit & D-Probit & Probit & D-Probit & Probit & D-Probit & Probit & D-Probit & $\mathrm{RE}$ & $\mathrm{RE}$ & $\mathrm{RE}$ \\
\hline Industry dummies & No & No & Yes & Yes & Yes & Yes & Yes & Yes & No & Yes & Yes \\
\hline Time dummies & No & No & Yes & Yes & Yes & Yes & Yes & Yes & No & Yes & Yes \\
\hline Legal form dummies & No & No & Yes & Yes & Yes & Yes & Yes & Yes & No & Yes & Yes \\
\hline Credit size & All & All & All & All & Small & Small & Large & Large & All & All & Large \\
\hline Firm random effects & No & No & No & No & No & No & No & No & Yes & Yes & Yes \\
\hline Number of observations & 1496 & 1496 & 1496 & 1496 & 748 & 748 & 748 & 748 & 1496 & 1496 & 748 \\
\hline Pseudo-R ${ }^{2}$ & 0.134 & 0.134 & 0.183 & 0.183 & 0.290 & 0.290 & 0.144 & 0.144 & ND & ND & ND \\
\hline Log-likelihood & -294.587 & -294.587 & -278.025 & -278.025 & -117.475 & -117.475 & -147.907 & -147.907 & -284.825 & -268.069 & -140.546 \\
\hline
\end{tabular}

Notes: A - shares of total assets, B - shares of current short-term liabilities. Small (large) credits are those below (above) the median of the credit share in current short-term liabilities. ND - not defined for panel probit, RE - random effects probit model. Standard errors are in parentheses. *,**,*** denote significance at the 10 , 5 and 1 per cent level, respectively. 
If banks have efficient credit evaluation tools for excluding the too risky firms in advance, and sufficient control or monitoring mechanisms over the activities of the SMEs during the duration of the loans, we would expect the influence of bank loans on defaults to be largely insignificant. By contrast, we find adverse and significant effects of bank loans (see specification P1 in Table 2) indicating that the creditor cannot enforce his controlling role, although the marginal change in the probability for an infinitesimal increase of bank loans (estimated by d-probit in specification P2) is relatively small compared to the effects of our control variables. Nevertheless, this effect is robust to the inclusion of time and industry dummies as well as the dummies indicating the legal form of the SMEs (see specifications P3 and P4).

However, the positive coefficient may largely reflect the higher default probabilities of highly indebted SMEs (debt channel), while the banks still own relatively efficient tools for assessing the a priori risk. Therefore, we split the estimations into two parts, based on the share of loans to current short-term liabilities. In the first sub-sample (see columns P5 and P6), we include only SMEs with loans below the median level of loans (that is, approximately 12 per cent of current short-term liabilities). In fact, we see that bank loans are insignificant in this sub-sample. By contrast, we find a highly positive and significant coefficient for severely indebted SMEs (above 12 per cent of current short-term liabilities) in specifications P7 and P8.

We also include random effects for the individual SMEs in specifications P9 and P10, although we have to keep in mind that we have only an unbalanced panel with a relatively short time dimension. Nevertheless, firm-specific effects cover all unobservable characteristics of the SMEs, and thus also reduce the possible selection bias (see Djankov and Murrel, 2002). This confirms the previous findings. In particular, 
the coefficient for bank loans is no longer significant, although it retains the positive sign, while all other determinants of defaults remain unchanged. It seems that unobservable firm-specific factors to a large extent explain the relationship between bank loans and defaults of the SMEs. However, default rates of large loans are also still positively related to bank loans also when we include firm-specific effects (specification P11). Thus, it seems that high indebtedness is of crucial importance for defaults. This result is consistent with the agency theory that incentives deteriorate in more highly indebted firms.

We included sectoral effects to selected specifications of (3) in order to cover for possible differences between the economic sectors. On the one hand, such differences can be driven by the different nature of the business. On the other hand, a bank may specialize on particular sectors. In fact, one third of the credit cases analyzed is given to the SMEs active in the industrial sector, while de la Rocha (2001) reports that about 15 per cent of firms are registered in industry. The difference is even larger for agriculture, which received about one quarter of all credits analyzed here although it represents less than six per cent of Slovak firms according to de la Rocha (2001). In turn, retail trade and other services might receive less credit than is their share in the economy (three quarters of all registered firms against about one third of the credits). However, those differences can be caused also by the higher need for the external financial funds in sectors with high fixed assets.

Figure 3 shows the estimated sectoral effects for the one-digit NACE industries according to selected specifications (see Table 2, columns P3, P7, P10, and P11) of (3). Industrial SMEs, as the largest category, were selected as the base sector for comparisons. For our base probit specification (see column P3 in Table 2), the estimated 
effects confirm approximately equal default probabilities between the sectors. Nevertheless, retail trade seems to be more secure than industry, while we find higher sectoral default probabilities for agriculture, construction, and other services.

However, the picture changes if we consider only large loans. Figure 3 shows that large loans in agriculture have much higher default probabilities than in any other sectors in Slovakia. This adverse effect in agriculture is also confirmed by panel probit estimation for large loans. In turn, the estimated effects for the remaining sectors also remain stable for different credit size and panel estimations.

\section{Figure 3: Estimated Sectoral Effects for Selected Specifications}

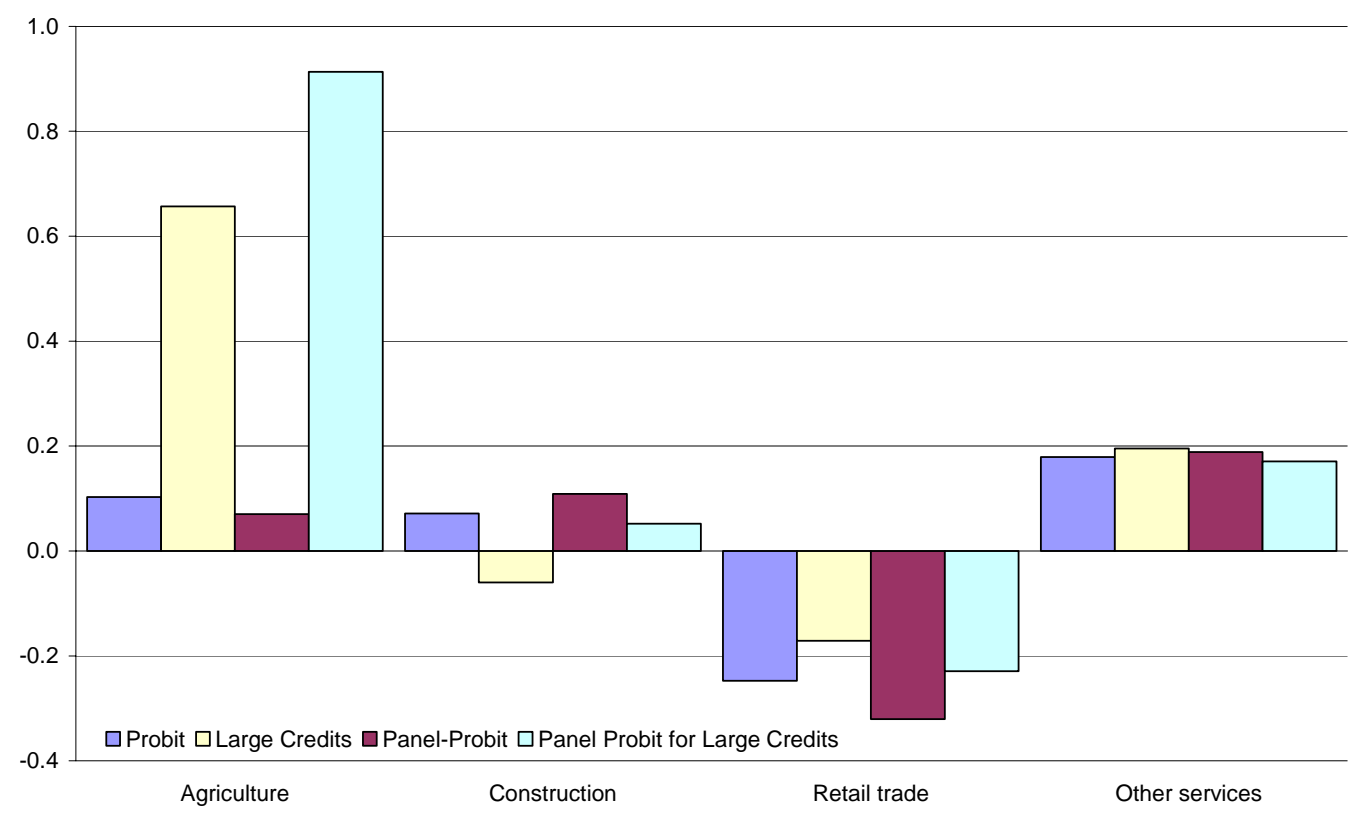

Note: See Table 2, specifications P3, P7, P10 and P11 for details on the other explanatory variables. Industry is selected as the base for comparisons. 


\subsection{Incentive Structure and the Effects of Legal Forms}

Our starting descriptive analyses already show that the legal form determines the liability of a debtor (see Section 3). For legal entities, a minimum endowment with equity is mandatory, but only at a relatively low level for the SMEs. In turn, natural persons are fully liable and may lose all their personal assets if they fail. Choosing to operate a business as a legal entity may therefore be the deliberate choice by an entrepreneur to limit its liability. Liability, however, has important effects on incentives. Therefore, we expect that natural persons are less likely to default than legal bodies (hypothesis 2).

Figure 4 confirms this hypothesis that natural persons are much less likely to default than other legal forms. However, the number (66 natural persons, of whon one defaulted) is possibly too low to draw final conclusions. The limited liability companies (S.R.O.) are slightly less risky than the joint stock companies (A.S.), according to our base probit specification. For large credits, however, the risk for the limited liability companies increases more than for the joint stock companies. The same behavior can be seen for panel probit for large credits.

This may reflect the different legal standards of these types of companies. The limited liability companies can be founded with a nearly negligible value of starting capital (only SKK 200,000 or approximately EUR 5,000). Unlike the joint stock companies, the limited liability companies are not obliged to provide any public reports for their business activity. As a result, there is anecdotal evidence that limited liability companies are less confident business partners than any other types of business, and this is confirmed by our results. 


\section{Figure 4: Estimated Legal-Form Effects for Selected Specifications}

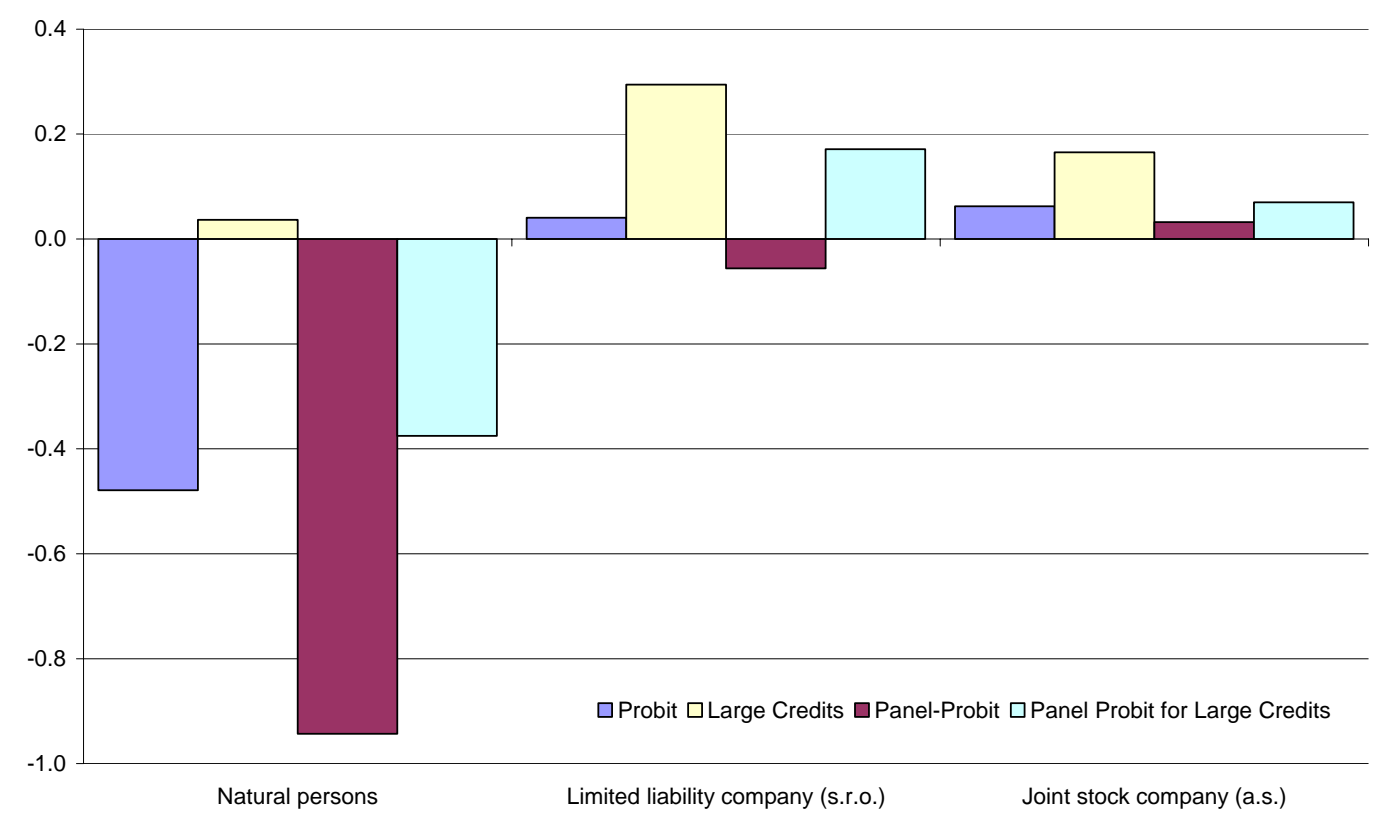

Note: See Table 2, specifications P3, P7, P10 and P11 for details on the other explanatory variables. State enterprises and cooperatives are selected as the base for comparisons.

\section{Conclusions}

We show that the loans to SMEs are a relatively well-performing segment of the credit market in Slovakia. On average, only 6.0 per cent of the SMEs defaulted on their loans between January 2000 and June 2005, which is generally comparable with developed markets.

Our results are somewhat ambiguous with regard to the relationship between indebtedness and default. Although there is a positive correlation between the default probabilities and indebtedness, we show that this is not statistically robust for the whole sample if the possible selection bias is treated by the including industry and legal-form effects as well as firm-specific effects for individual companies. In contrast, for the firms with above average indebtedness we find that the positive relationship between 
default probabilities and higher indebtedness is significant. This implies that the debt burden may play a significant role for further development of the companies analyzed.

With respect to the role of incentives, our results confirm that businesses of natural persons are much less likely to default than legal entities with restricted liability of their owners. This is consistent with the effects of full personal liability which provides proper incentives to debtors. Finally, our results confirm that higher profitability and higher liquidity lower the default probabilities of the SMEs significantly, as stated in the last hypothesis.

Although our results may also be applicable to other countries of the region, we have to keep in mind that we are studying a period in which the development of loans to the SMEs has been relatively stable in Slovakia. Nevertheless, our results indicate that the risk of lending to SMEs is comparable to those in Western markets, but we also find important differences between sectors, legal forms and, especially, credit size. These differences indicate sources of risk in the expansion of credits to the SMEs. Thus, attempts to gain market shares may come at the cost of a higher risk. This might be the case especially if loan growth is achieved mainly by larger credits to both new or incumbent customers. 


\section{References}

Altman, Edward I., 1968. Financial Ratios, Discriminant Analysis and the Prediction of Corporate Bankruptcy. Journal of Finance 23, 589-609.

Altman, Edward I., 1989. Measuring Corporate Bond Mortality and Performance. Journal of Finance 44, 909-922.

Altman, Edward I., Suggitt, Heather J., 2000. Default Rates in the Syndicated Bank Loan Market: A Mortality Analysis. Journal of Banking and Finance 24, 229-253.

Asarnow, Elliot, Edwards, David, 1995. Measuring Loss on Defaulted Bank Loans: A 24 Yr. Study. Journal of Commercial Lending, March, 11-19.

Asch, Latimer, 1995. How the RMA/Fair, Isaac Credit-Scoring Model Was Built. Journal of Commercial Lending 77, 12-16.

Beaver, William H., 1966. Financial Ratios as Predictors of Failure. Journal of Accounting Research 4, 71-111.

Berger, Allen N., Frame, W. Scott, Miller, Nathan H., 2005. Credit Scoring and the Availablity, Price and Risk of Small Business Credit. Journal of Money, Credit, and Banking 37, 191-222.

Bester, Helmut, 1987. The Role of Collateral in Credit Markets with Imperfect Information. European Economic Review 31, 887-899.

Bester, Helmut, 1994. The Role of Collateral in a Moral Hazard Model of Debt Renegotiation. Journal of Money, Credit, and Banking 26, 72-86.

Bilsen, Valentijn, Konings, Jozef, 1998. Job Creation, Job Destruction, and Growth of Newly Established, Privatized, and State-Owned Enterprises in Transition Economies: Survey Evidence from Bulgaria, Hungary, and Romania. Journal of Comparative Economics 26, 429-445. 
Blazy, Régis, Weill, Laurent, 2006. Why do Banks Ask for Collateral? Mimeo, University of Strasbourg. Available at http://ssrn.com/abstract=675803 (October 2006).

Breyer, Peter, 2004. Central and Eastern Europe - The Growth Market for Austrian Banks. Monetary Policy \& The Economy No. 3. Oesterreichische Nationalbank, Vienna, 63-88.

Bris, Arturo, Welch, Ivo, Zhu, Ning, 2006. The Costs of Bankruptcy: Chapter 7 Liquidation vs. Chapter 11 Reorganization. Journal of Finance, forthcoming.

Carty, Lea V., Lieberman, Dana, 1998. Defaulted Bank Loan Recoveries. Moody’ Investors Services.

Chan-Lau, Jorge A., 2006. Fundamentals-Based Estimation of Default Probabilities: A Survey. Working Paper No. 149. IMF, Washington.

Coricelli, Fabrizio, Mucci, Fabio, Revoltella, Debora, 2006. Household Credit in the New Europe: Lending Boom or Sustainable Growth? Discussion Paper No. 5520. CEPR, London.

Das, Sanjiv R., Duffie, Darrell, Kapadia, Nikunj, Saita, Leandro, 2006. Common Failings: How Corporate Defaults are Correlated. Journal of Finance, forthcoming.

De la Rocha, Manuel, 2001. Corporate Sector and SME's Environment in the Slovak Republic. Background Paper. World Bank, Washington.

Djankov, Simeon, Murrell, Peter, 2002. Enterprise Restructuring in Transition: A Quantitative Survey. Journal of Economic Literature 40, 739-792. 
Duenwald, Christoph, Gueorguiev, Nikolay, Schaechter, Andrea, 2005. Too Much of a Good Thing? Credit Booms in Transition Economies: The Cases of Bulgaria, Romania, and Ukraine. IMF Working Paper WP/05/128. International Monetary Fund, Washington D.C.

EBRD, 2005a. Transition Report 2005, Business in transition. EBRD, London.

EBRD, 2005b. The Business Environment and Enterprise Performance Survey (BEEPS) 2005: A brief report on observations, experiences and methodology from the survey. EBRD, London.

Franks, Julian R., Loranth, Gyongyi, 2005. A Study of Inefficient Going Concerns in Bankruptcy. CEPR Discussion Paper No. 5035. CEPR, London.

Grossman, Robert J., Brennan, William T., Vento, Jennifer, 1997. Syndicated Bank Loan Recovery Study, Structured Finance Credit Facilities Report. Fitch IBCA.

Hainz, Christa, 2003. Bank Competition and Credit Markets in Transition Economies. Journal of Comparative Economics 31, 223-45.

Holmström, Bengt, 1996. Financing of Investment in Eastern Europe: A Theoretical Perspective. Industrial and Corporate Change 5, 205-237.

Honohan, Patrick, Klingebiel, Daniela, 2000. Controlling the Fiscal Costs of Banking Crises. Policy Research Working Paper No. 2441. World Bank, Washington.

Klapper, Leora, Sarria-Allende, Virginia, Zaidi, Rida, 2006. A Firm-Level Analysis of Small and Medium Size Enterprise Financing in Poland. Policy Research Working Paper No. 3984. World Bank, Washington.

Levine, Ross, 2006. Finance and Growth: Theory, Evidence, and Mechanisms. In: Aghion, Philippe, Durlauf, Steven N. (Eds.), Handbook of Economic Growth. NorthHolland Elsevier Publishers, Amsterdam, forthcoming. 
Lízal, Lubomir, Švejnar, Jan, 2001. Investment, Credit Rationing, and the Soft Budget Constraint: Evidence From Czech Panel Data. The Review of Economics and Statistics 84, 353-370.

Mester, Loretta J., 1997. What's the Point of Credit Scoring? Business Review, Federal Reserve Bank of Philadelphia, 3-16.

NBS, 2006. Monthly Credit Reports (Mesačný výkaz o úveroch). National Bank of Slovakia. Available at http://www.nbs.sk/BANKY/STAT/UVERY.HTM\#v3-12 (October 2006). 


\section{Endnotes}

${ }^{1}$ For example, the costs of the East Asian financial crisis in 1997 are estimated at $25-50$ per cent of GDP for Indonesia, Korea and Thailand. Even the banking crisis in Finland in 1991 had costs of more than 10 per cent of GDP. During the last decades, banking and financial crises occurred in most regions of the world (Honohan and Klingebiel, 2000).

${ }^{2}$ According to EBRD (2005b), an overwhelming majority (92 per cent) of loans to SMEs in Slovakia had to pledge collateral that was a high 150 per cent of the loan value. Nevertheless, the recovery rates of loans may be very different in individual cases. Unfortunately, our data set does not include any information on collateral.

${ }^{3}$ Moreover, a recent study shows that corporate failings are correlated (Das et al., 2006). New data are used to measure the costs of different bankruptcy procedures relative to each other (Bris, Welch and Zhu, 2006, for the US, and Franks and Loranth, 2005, for Hungary).

${ }^{4}$ The debtors are unlikely to default if credits are already nearly repaid. The inclusion of those firms could bias the results in earlier years of the credit period.

${ }^{5}$ For comparison, the credits to private households grew by 28.9 per cent on average between 1999 and 2005. In 2004 and 2005, growth rates reached 37 per cent and 41 per cent, respectively.

6 Klapper et al. (2006) show that by using balance sheet data for the years between 1998 and 2002 smaller SMEs in Poland tend to be more liquid.

${ }^{7}$ A broad comparison with the firms analyzed in this contribution may be given by the S\&P rating of the long-run bank activities, which is BB. The SMEs (with no ranking available) instead could represent a rather more risky activity of the bank, which is then comparable with the latter firm group analyzed by Altman and Suggit (2000).

${ }^{8}$ According to EBRD (2005b), approximately 56 per cent of Slovak SMEs had no loans in 2005.

${ }^{9}$ Estimation results for a broader set of explanatory variables are available upon request from the authors. 


\section{DAVIDSON INSTITUTE WORKING PAPER SERIES - Most Recent Papers}

The entire Working Paper Series may be downloaded free of charge at: www.wdi.umich.edu

CURRENT AS OF 12/07/06

\begin{tabular}{|c|c|c|}
\hline Publication & Authors & Date \\
\hline $\begin{array}{l}\text { No. 854: Default Rates in the Loan Market for SMEs: Evidence from } \\
\text { Slovakia }\end{array}$ & $\begin{array}{l}\text { Jarko Fidrmuc, Christa Hainz and } \\
\text { Anton Maleisch }\end{array}$ & Nov 2006 \\
\hline $\begin{array}{l}\text { No. 853: Monetary Policy before Euro Adoption: Challenges for EU } \\
\text { New Members }\end{array}$ & $\begin{array}{l}\text { Jan Filáček, Roman Horváth and } \\
\text { Michal Skorepa }\end{array}$ & Nov 2006 \\
\hline $\begin{array}{l}\text { No. 852: Private-Sector Credit in Central \& Eastern Europe: New } \\
\text { (Over) Shooting Stars? }\end{array}$ & $\begin{array}{l}\text { Balázs Égert, Peter Backé and } \\
\text { Tina Zumer }\end{array}$ & Nov 2006 \\
\hline $\begin{array}{l}\text { No. 851: Interest Rate Pass-Through in Central \& Eastern Europe: } \\
\text { Reborn from Ashes Merely to Pass Away? }\end{array}$ & $\begin{array}{l}\text { Balázs Égert,Jesus Crespo- } \\
\text { Cuaresma and Thomas Reininger }\end{array}$ & Nov 2006 \\
\hline $\begin{array}{l}\text { No. 850: Monetary Transmission Mechanism in Central \& Eastern } \\
\text { Europe: Gliding on a Wind of Change }\end{array}$ & $\begin{array}{l}\text { Fabrizio Coricelli, Balázs Égert } \\
\text { and Ronald MacDonald }\end{array}$ & Nov 2006 \\
\hline No. 849: Crime Distribution \& Victim behavior During a Crime Wave & $\begin{array}{l}\text { Rafael Di Tella, Sebastian Galiani } \\
\text { and Ernesto Schargrodsky }\end{array}$ & Nov 2006 \\
\hline $\begin{array}{l}\text { No. 848: Real-Time Time-Varying Equilibrium Interest Rates: Evidence } \\
\text { on the Czech Republic }\end{array}$ & Roman Horváth & Oct 2006 \\
\hline $\begin{array}{l}\text { No. 847: Financial Accelerator Effects in the Balance Sheets of Czech } \\
\text { Firms }\end{array}$ & Roman Horváth & Nov 2006 \\
\hline $\begin{array}{l}\text { No. 846: Central Bank Interventions, Communication \& Interest Rate } \\
\text { Policy in Emerging European Economies }\end{array}$ & Balázs Égert & Nov 2006 \\
\hline $\begin{array}{l}\text { No. 845: On the Role of Absorptive Capacity: FDI Matters to } \\
\text { Growth }\end{array}$ & Yuko Kinishita and Chia-Hui Lu & Nov 2006 \\
\hline No. 844: Current Account Sustainability in Selected Transition Countries & Aleksander Aristovnik & Nov 2006 \\
\hline $\begin{array}{l}\text { No. 843: Policy, Economic Federalism \& Product Market Entry: The } \\
\text { Indian Experience }\end{array}$ & $\begin{array}{l}\text { Sumon Bhaumik, Shubhashis } \\
\text { Gangopadhyay and Shagun } \\
\text { Krishnan }\end{array}$ & Nov 2006 \\
\hline No. 842: Price Mobility of Locations & Konstantin Gluschenko & Oct 2006 \\
\hline $\begin{array}{l}\text { No. 841: The Role of Foreign Direct Investment in the Firm Selection } \\
\text { Process in a Host Country: Evidence from Slovenia }\end{array}$ & Katja Zajc Kejzar & Sept 2006 \\
\hline $\begin{array}{l}\text { No. 840: Family Ownership and Control in Large Firms: The Good, The } \\
\text { Bad, The Irrelevant - and Why? }\end{array}$ & Mike Peng and Yi Jiang & Oct 2006 \\
\hline No. 839: Price Linkages of Russian Regional Markets & Konstantin Gluschenko & Sept 2006 \\
\hline $\begin{array}{l}\text { No. 838: The Effect of Pre-Primary Education on Primary School } \\
\text { Performance }\end{array}$ & $\begin{array}{l}\text { Samuel Berlinski, Sebastian } \\
\text { Galiani and Paul Gertler }\end{array}$ & July 2006 \\
\hline $\begin{array}{l}\text { No. 837: Do Investors Value Insider Trading Laws? International } \\
\text { Evidence }\end{array}$ & Laura Beny & Aug 2006 \\
\hline No. 836: How corruption Hits People When They Are Down & Jennifer Hunt & Aug 2006 \\
\hline No. 835: Mirage at the Bottom of the Pyramid & Aneel Karnani & Aug 2006 \\
\hline $\begin{array}{l}\text { No. 834: Ownership concentration and firm performance: Evidence from } \\
\text { an emerging market }\end{array}$ & Irena Grosfeld & June 2006 \\
\hline $\begin{array}{l}\text { No. 833: Institutions, Networks and Entrepreneurship Development in } \\
\text { Russia: An Exploration }\end{array}$ & Ruta Aidis and Saul Estrin & June 2006 \\
\hline $\begin{array}{l}\text { No. 832: Long \& Short Run Linkages in CEE Stock Markets: } \\
\text { Implications for Portfolio Diversification \& Stock Market Integration }\end{array}$ & $\begin{array}{l}\text { Manolis Syllignakis and Georgios } \\
\text { Kouretas }\end{array}$ & July 2006 \\
\hline $\begin{array}{l}\text { No. 831: Inequality, Fiscal Capacity and the Political Regime } \\
\text { Lessons from the Post-Communist Transition }\end{array}$ & $\begin{array}{l}\text { Christopher J. Gerry and Tomasz } \\
\text { Mickiewicz }\end{array}$ & July 2006 \\
\hline
\end{tabular}

